AL IBTIDA: JURNAL PENDIDIKAN GURU MI (2020) Vol 7 (1) : 46-55

DOI: http://dx.doi.org/ 10.24235/al.ibtida.snj.v7i1.6212

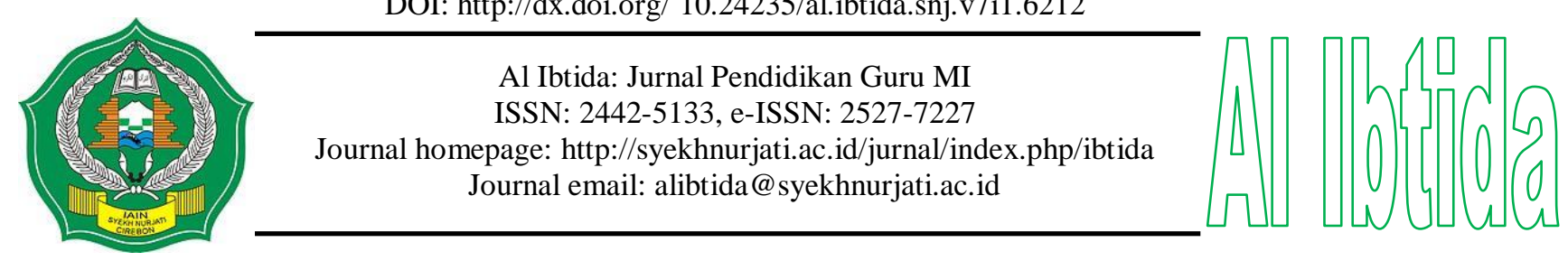

\title{
The Analysis of Critical Thinking Skills of Primary School Teacher Candidates in Solving Mathematical Problems
}

\author{
Ahmad Arifuddin* \\ *Department of Madrasah Ibtidaiyah Teacher Education, Faculty of Tarbiyah dan Teacher Training, \\ IAIN Syekh Nurjati Cirebon, Indonesia \\ Email: arief.udien4@gmail.com
}

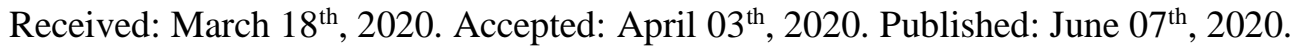

\begin{abstract}
This study is intend to describe the critical thinking skills of primary school (MI/SD) teachers candidate and the obstacles they faced in solving mathematical problems. This research is a qualitative research with the research subjects are 36 madrasah ibtidaiyah teacher education students (PGMI), in the fifth semester of IAIN Syekh Nurjati Cirebon. The data collection techniques used are tests and interviews. Meanwhile, the research data were analyzed using descriptive analysis techniques related to critical thinking skills indicators. The results showed that the average of critical thinking ability of primary school teacher candidates in solving mathematical problems especially in geometry material was classified as good, which amounted to 73.57. They are able to formulate problems, determine facts, and use correct evidence in solving mathematical problems. However, most of them have not been able to provide follow-up explanations correctly, thus impacting the difficulty in drawing conclusions. Therefore, a lecturer must be able to build a learning environment that is able to develop their critical thinking to become a qualified teacher.
\end{abstract}

Keywords: critical thinking, mathematics, MI/SD teacher candidate.

\begin{abstract}
Abstrak
Penelitian ini bertujuan untuk mendeskripsikan kemampuan berpikir kritis calon guru sekolah dasar (MI/SD) dan kendala yang dihadapi calon guru MI/SD dalam menyelesaikan masalah matematika. Penelitian ini merupakan penelitian kualitatif deskriptif dengan subyek penelitian yaitu 36 mahasiswa pendidikan guru madrasah ibtidaiyah (PGMI) semester V IAIN Syekh Nurjati Cirebon. Teknik pengumpulan data yang digunakan adalah tes dan wawancara. Sementara itu data hasil penelitian dianalisis menggunakan teknik analisis deskriptif dengan mengacu indikator kemampuan berpikir kritis. Hasil penelitian menunjukkan bahwa rata-rata kemampuan berpikir kritis calon guru MI/SD dalam menyelesaikan masalah matematika materi geometri tergolong baik, yakni sebesar 73.57. Calon guru MI/SD sudah mampu merumuskan masalah, menentukan fakta, dan menggunakan buktibukti yang benar dalam menyelesaikan masalah matematika. Namun demikian, sebagian besar calon guru MI/SD belum mampu memberikan penjelasan lanjutan dengan benar, sehingga berdampak pada kesulitan dalam menarik kesimpulan. Oleh karena itu, seorang dosen harus mampu membangun lingkungan belajar yang mampu mengembangkan pemikiran berpikir kritis calon guru MI/SD, agar
\end{abstract}


kemampuan berpikir kritis calon guru MI/SD meningkat dan menjadi guru yang berkualitas.

Kata kunci: berpikir kritis, matematika, calon guru MI/SD.

\section{INTRODUCTION}

Mathematics is one branch of science which studies about symbols and numbers. This is taught from primary to tertiary level so that students have the ability to think logically, analytically, systematically, critically and creatively. Zetriuslita, Ariawan, \& Nufus (2016) revealed that mathematics subject should be taught through activities that will help students in analytical development, critical reasoning, solving the problem and communication skills.

In addition, along with the development of science and technology that is changing so fast, demanding abilities that must be possessed by someone in the 21 st century or the age of the industrial revolution 4.0 is far from the capabilities needed by someone in the past century (Arifuddin, 2019). One of the demands is the ability to think critically (critical thinking) (Scott, 2017). The critical thinking ability (problem solving) is the most important component in mathematics (National Council of Teachers of Mathematics, 2000). This is in line with Lunenburg's (2011) research which revealed that the concept of critical thinking is one of the most significant trends in education, because critical thinking is needed to be able to succeed in living this life (Biber, Tuna, \& Incikabi, 2013).

According to Ennis (2011), critical thinking is reasonable, reflective process that is focused on deciding what to believe or do. Besides, Cahyana, Kadir, \& Gherardini (2017) defines critical thinking as a directed and clear process used in mental activities such as solving the problems, making decisions, persuading, analyzing assumptions, and conducting scientific research. This is also reinforced by the statement (Lipman, 1987); (Kurniasih, 2010) which says that critical thinking is an organized mental process and plays a role in decision making and problem solving as well as strategies for learning new concepts. Kurniawan (2016) concluded that critical thinking is one of the highest levels of a person in thinking, which starts from memory, basic thinking, and critical thinking.

Therefore, the ability to think critically is a very important thing that must be possessed by teachers candidates/students, because problems in all aspects of modern life are increasingly complex and high (Sari \& Putra, 2015); (Dwijananti \& Yulianti, 2010). With the ability to think critically possessed by students, they are expected to be able to examine and solve various problems that will later be found in the school environment appropriately (Fakhriyah, 2014). In addition, critical thinking has also become one of the tools used in everyday life. Its functions is to solve several problems, because it involves logical reasoning, 
interpreting, analyzing and evaluating information, and enable to someone in making the right and correct decisions (Chukwuyenum, 2013).

However, in reality, students' critical thinking skills in mathematics learning are still low. This can be seen from the 2015 TIMSS (Trends in International Mathematics and Science Study) states that Indonesia ranks 44 th out of the 49 countries that participated in TIMSS, where Indonesia ranks under the United Arab Emirates, Bahrain, Qatar, Iran and Oman even far below Singapore. In addition, $50 \%$ of students in Indonesia are only able to reach in low level of thinking, while in Singapore $50 \%$ of students are able to reach advanced levels (Mullis, Martin, Foy, \& Hooper, 2015). It means that the ability of students in Indonesia in learning mathematics $50 \%$ is only limited to being able to know, not to the stage of reasoning at a high level (critical thinking).

Previous studies related to critical thinking have been carried out by several researchers, including Kurniasih (2010) who examined the critical thinking skills of students of Mathematics Education Study Program, Faculty of Mathematics and Natural Science, State University of Semarang on the concept of material and function derived theorems; Aizikovitsh-udi \& Cheng (2015) who examined the ability to think critically from the level of kindergarten (kindergarten) to high school (high school); Biber et al., (2013); Incikabi, Tuna, \& Biber, (2013) examined the critical thinking abilities of prospective elementary school mathematics teachers in terms of gender, semester level, and type of high school; Firdaus, Kailani, \& Bakar (2015) who examined the ability to think critically on integral material; Gunawan, Suraya, \& Tryanasari, (2014); Cahyana et al., (2017) who examined the ability to think critically in scientific literacy; Rohaeti, (2010) who examined the ability to think critically on social arithmetic material; and Kim, Sharma, Land, \& Furlong (2013) who examined the ability to think critically in general science courses.

Meanwhile, the research conducted by researcher is related to the critical thinking ability of primary school teacher candidates in solving mathematical problems, especially in geometry material. This study is intended to describe the ability of teacher candidates to think critically and the obstacles faced them in solving mathematical problems, especially in geometry. In analyzing critical thinking skills of primary school teacher candidates, researcher refer to the indicators of critical thinking skills proposed by Ennis (2011), namely formulating the problem, determining the facts, using correct evidence, drawing conclusions in accordance with the facts, providing further explanation, and decision making ability. 


\section{METHODS}

This research is qualitative descriptive study. This study aims to describe the critical thinking skills of primary school teacher candidates in solving mathematical problems. This is based on the definition of qualitative research presented by Moleong (2017) that qualitative research is research that aims to understand phenomena about what is experienced by research subjects related to behavior, perceptions, actions, etc. holistically and by describing words and language in a specific scientific context and utilizing various scientific methods.

The subjects in this study were 36 PGMI students in semester V of IAIN Syekh Nurjati Cirebon in the academic year 2019/2020. Meanwhile, the object of research is the ability to think critically in learning geometry material and the obstacles faced by students in solving mathematical problems. Meanwhile, the data in this study consisted of quantitative and qualitative data. Quantitative data in the form of critical thinking skills test scores and qualitative data were obtained from in-depth interviews with primary school teacher candidate about the obstacles faced in solving mathematical problems.

Data collection techniques applied was tests and interviews. The test referred to in this study is a test of critical thinking skills on geometry material. This test consists of a test description of problem solving arranged based on indicators of critical thinking skills. Meanwhile, interviews are one method of data collection by means of communication between data collectors and data sources. This interview technique is used to explore the obstacles faced by students in solving mathematical problems. The in-depth interview process is carried out based on the interview guidelines that have been prepared, but the range of questions asked may change, depending on the answers / explanations raised by primary school teacher candidates. Therefore, spontaneous questions can be asked based on their previous responses to explore more in-depth information about the obstacles faced by primary school teacher candidates in solving mathematical problems.

Furthermore, the technique of data analysis =in this study was two data analysis techniques, namely quantitative data analysis techniques and qualitative data. Quantitative data analysis techniques are used to process data on the results of tests of critical thinking skills of primary school teacher candidates. Data in the form of critical thinking skills test results were analyzed according to the scoring guidelines made, then re-analyzed indicators to determine the ability of critical thinking of primary school teacher candidates. Furthermore, qualitative data analysis techniques are used to analyze the data from interviews. Miles, Huberman, \& Huberman, M. A., Huberman (1994) explains that the activities in qualitative data analysis are carried out continuously until it is complete, so that the data is saturated. The 
data analysis in this study starts from the field using descriptive analytic methods, namely by describing, interpreting, and presenting data and drawing conclusions from all things that are the focus of research.

\section{RESULTS AND DISCUSSION}

\section{The Description of Critical Thinking Ability of Primary School Teacher Candidate}

In general, the critical thinking skills data of primary school teacher candidates in solving mathematical problems in geometry material can be presented in the following table 1:

Table 1. The Data of Critical Thinking Ability of Primary School Teacher Candidate

\begin{tabular}{lrrrrrr}
\hline & \multicolumn{6}{c}{ Descriptive Statistics } \\
& N & Minimum & Maximum & Mean & Std. Deviation & Variance \\
\hline Critical Thinking & 36 & 45 & 93 & 73.64 & 12.121 & 146.923 \\
Valid N (listwise) & 36 & & & & & \\
\hline
\end{tabular}

The table shows that the average of critical thinking skills of primary school teacher candidates is 73.64 , with the highest value of 93 and the lowest value of 45 . If the average value of critical thinking skills of primary school teacher candidates is converted using a reference rating benchmark (PAP) (Nurbayani, 2012), then the average value of critical thinking skills of primary school teacher candidates is in the moderate/good enough category. So it can be concluded that the ability to think critically primary school teacher candidates in solving mathematical problems, especially in geometry material in general is quite good.

\section{Analysis on Critical Thinking Ability of Primary School Teacher Candidates}

To analyze the critical thinking skills of primary school teacher candidates, researchers used the critical thinking skills indicators that have been put forward by Ennis (2011), namely formulating the problem, determining the facts, using correct evidence, drawing conclusions in accordance with the facts, providing further explanation, and decision making ability. The data on the results of the analysis of the ability to think critically primary school teacher candidates in solving mathematical problems, especially in the geometry material can be presented as table 2 below:

Table 2.The Analysis of Critical Thinking Ability of Primary School Teacher Candidates

\begin{tabular}{llll}
\hline No & Indicators & Able & Unable \\
\hline 1 & Formulating the problem & $94,4 \%$ & $5,6 \%$ \\
2 & Determining the existing facts & $100 \%$ & $0 \%$ \\
3 & Using correct evidence & $91,6 \%$ & $8,4 \%$ \\
4 & Drawing conclusion based on facts & $19,4 \%$ & $80,6 \%$ \\
5 & Giving further explanation & $16,6 \%$ & $83,4 \%$ \\
6 & Making decision & $66,6 \%$ & $43,4 \%$ \\
\hline
\end{tabular}


Table 2 shows that $94.4 \%$ or 34 primary school teacher candidates have been able to formulate mathematical problems correctly, only 2 primary school teacher candidates or $5.6 \%$ who have not been able to formulate math problems correctly. Furthermore, for indicators to determine existing facts, all 36 primary school teacher candidates have been able to determine facts correctly. Meanwhile, for indicators using correct evidence, almost all primary school teacher candidates namely 33 people or $91.6 \%$ have been able to use correct evidence, only 3 primary school teacher candidates or $8.4 \%$ who have not been able to use right evidence. So it can be concluded that the three indicators are in the high category. The categorization of values refers to criterion reference assessment (PAP) which was conducted by (Nurbayani, 2012).

Furthermore, for the indicators of drawing conclusions according to facts, only 7 primary school teacher candidates $(19.4 \%)$ have been able to draw conclusions correctly, 29 primary school teacher candidates $(80.6 \%)$ have not been able to draw conclusions correctly. For indicators providing further explanation, only 6 primary school teacher candidates (16.6\%) have been able to provide further explanation correctly, 30 other primary school teacher candidates $(83.4 \%)$ have not been able to provide further explanation correctly. So it can be concluded that the two indicators above are in the low category. Whereas for indicators of ability to make decisions in the medium category, 24 primary school teacher candidates $(66.6 \%)$ have been able to make decisions correctly, 12 other primary school teacher candidates $(34.4 \%)$ have not been able to make decisions correctly.

\section{Some Obstacles Faced by Primary School Teacher Candidates in Solving Mathematical Problems}

Based on the interviews with a number of primary school teacher candidates in October 2019, it is said that the obstacles and difficulties faced by primary school teacher candidates in solving mathematical problems, especially geometry, are primary school teacher candidates not accustomed to working on critical thinking questions, so they have difficulty in doing it. Most primary school teacher candidates have difficulty in drawing conclusions from what they have done.

Furthermore, primary school teacher candidates also have difficulty in providing further explanation of the problems they are working on. The difficulty arises because they do not understand how to convert units of measurement, do not understand the concept of geometry well, and are unable to relate the relationships between shapes in a combined arrangement of flat shapes. In addition, primary school teacher candidates are also not careful in working on critical thinking questions, so some of the answers are not quite right. 
Based on the description of the results above shows that the average of critical thinking skills of primary school teacher candidates in solving mathematical problems especially geometry material is classified as moderate / good enough, which is equal to 73.64. The results of this study are in line with the results of research conducted by Aktas \& Ünlü (2013); Biber et al., (2013); Incikabi, Tuna, \& Biber (2013) who revealed that elementary mathematics teachers candidates in Turkey have a moderate level of logical thinking skills and critical thinking dispositions. Their critical thinking skills are not much influenced by differences in grade / semester level and type of secondary school from which the mathematics teacher candidates come, and between the disposition of critical thinking and the selfish thinking of elementary mathematics teacher candidates in Turkey are not positively correlated. Furthermore, the results of the research, conducted by Kurniasih (2010) also revealed that most of the critical thinking abilities of students of Mathematics Education Study Program, Faculty of Mathematics and Natural Science, State University of Semarang belong to the category of low critical thinking.

The results of the analysis of the ability to think critically primary school teacher candidates in solving mathematical problems, especially in geometry, also shows that primary school teacher candidates have been able to formulate the problem correctly, able to determine the facts, and be able to use the evidence correctly. This means that the mastery of geometry concepts for primary school teacher candidates is good enough. Because of the understanding of concepts is an important component in achieving learning goals (RittleJohnson, Siegler, \&Alibali, 2001). Riley (1984) suggested that the better mastery of one's concepts is the better one's ability to solve problems. And this will certainly have an impact on increasing learning achievement in mathematics (Hidayat \& Iksan, 2015).

However, most primary school teacher candidates have not been able to provide further explanation correctly, so that it has an impact on the difficulty in drawing conclusions. The inability to provide further explanation correctly is due to the procedural skills of primary school teacher candidates and the knowledge possessed by them in solving mathematical problems is incomplete (Widodo \& Sujadi, 2015). Whereas, these procedural skills are part of the mathematical skills needed to solve the problems (Kilpatrick, Swafford, \& Findell, 2001). In addition, primary school teacher candidates are also not accustomed to solving non-routine problems (problem solving problems) (Amir, 2015). The results of this study are also in line with the research results conducted by Zetriuslita et al. (2016); Widiantari, Suarjana, \& Kusmariyatni (2016) who revealed that the difficulty of mathematics teachers candidates in solving critical thinking problems is that mathematics teacher candidates have not been able 
to justify the concepts well and have not been able to analyze an algorithm. For this reason, a lecturer must be able to develop a learning environment to stimulate critical thinking primary school teacher candidates, so that the critical thinking ability of primary school teacher candidates increases and becomes a quality teacher (Biber et al., 2013; Incikabi et al., 2013; Nuryanti, Zubaidah, \& Diantoro, 2018).

\section{CONCLUSION}

Based on the description of the results of the study and the discussion above it can be concluded that the average critical thinking ability of primary school teacher candidates in solving mathematical problems especially in geometry material is classified as moderate/ good enough, which is equal to 73.64. Most primary school teacher candidates have been able to formulate problems, determine available facts and use evidence properly. However, most primary school teacher candidates have not been able to provide further explanation correctly, so that it has an impact on the difficulty in drawing conclusions. Therefore, a lecturer must be able to build a learning environment that is able to develop critical thinking of primary school teacher candidates to make them become qualified teachers.

\section{REFERENCES}

Aizikovitsh-udi, E., \& Cheng, D. (2015). Developing Critical Thinking Skills from Dispositions to Abilities: Mathematics Education from Early Childhood to High, (March), 455-462.

Aktas, G. S., \& Ünlü, M. (2013). Critical Thinking Skills of Teacher Candidates of Elementary Mathematics. Procedia - Social and Behavioral Sciences, 93, 831-835. https://doi.org/10.1016/j.sbspro.2013.09.288.

Amir, M. F. (2015). Analisis Kesalahan Mahasiswa PGSD Universitas Muhammadiyah dalam Menyelesaikan Soal Pertidaksamaan Linear. Jurnal Edukasi, 1(2), 131-145.

Arifuddin, A. (2019). Students' Critical and Creative Thinking Skills on Mathematics Learning in Madrasah Ibtidaiyah. Auladuna: Jurnal Pendidikan Dasar Islam, 6(1), $38-49$.

Biber, A. C., Tuna, A., \& Incikabi, L. (2013). An investigation of critical thinking dispositions of mathematics teacher candidates. Educational Research, 4(February), 109-117.

Cahyana, U., Kadir, A., \& Gherardini, M. (2017). Relasi Kemampuan Berpikir Kritis dalam Kemampuan Literasi Sains pada Siswa Kelas IV Sekolah Dasar. Sekolah Dasar, 26(1), $14-22$.

Chukwuyenum, A. N. (2013). Impact of Critical thinking on Performance in Mathematics among Senior Secondary School Students in Lagos State, 3(5), 18-25.

Dwijananti, P., \& Yulianti, D. (2010). Pengembangan Kemampuan Berpikir Kritis Mahasiswa Melalui Pembelajaran Problem Based Instruction Pada Mata Kuliah Fisika Lingkungan. Jurnal Pendidikan Fisika Indonesia, 6, 108-114. 
Ennis, R. H. (2011). The Nature of Critical Thinking: Outlines of General Critical Thinking Disposition and Abilities. In Sixth International Conference on Thinking at MIT (pp. 1-8). Cambridge: MA.

Fakhriyah, F. (2014). Penerapan Problem Based Learning dalam Upaya Mengembangkan Kemampuan Berpikir Kritis Mahasiswa. Jurnal Pendidikan IPA Indonesia, 3(1), 95101.

Firdaus, F., Kailani, I., \& Bakar, M. N. Bin. (2015). Developing Critical Thinking Skills of Students in Mathematics Learning. Journal of Education and Learning, 9(3), 226-236.

Gunawan, I., Suraya, S. N., \& Tryanasari, D. (2014). Hubungan Kemampuan Berpikir Kreatif dan Kritis dengan Prestasi Belajar Mahasiswa pada Matakuliah Konsep Sains II Prodi PGSD IKIP PGRI Madiun. Premiere Educandum, 4(1), 10-40. Retrieved from http://e-journal.ikippgrimadiun.ac.id/index.php/PE/article/view/304.

Hidayat, R., \& Iksan, Z. H. (2015). The Effect of Realistic Mathematic Education on Students 'Conceptual Understanding of Linear Progamming, (December), 2438-2445.

Incikabi, L., Tuna, A., \& Biber, A. C. (2013). An Analysis Of Mathematics Teacher Candidates' Critical Thinking Dispositions and Their Logical Thinking SKill. Journal of International Education Research, 9(3), 257-266.

Kilpatrick, J., Swafford, J., \& Findell, B. (2001). Adding It Up: Helping Children Learn Mathematics. Washington DC: National Academy Press.

Kim, K., Sharma, P., Land, S. M., \& Furlong, K. P. (2013). Effects of Active Learning on Enhancing Student Critical Thinking in an Undergraduate General Science Course. Innov High Educ, 38, 223-235. https://doi.org/10.1007/s10755-012-9236-X.

Kurniasih, A. W. (2010). Penjenjangan Kemampuan Berpikir Kritis dan Identifikasi Tahap Berpikir Kritis Mahasiswa Prodi Pendidikan Matematika FMIPA UNNES dalam Menyelesaikan Masalah Matematika. In Seminar Nasional Matematika dan Pendidikan Matematika (Vol. 0, pp. 486-493). Yogyakarta: FMIPA Universitas Negeri Yogyakarta. Retrieved from http://karyailmiah.um.ac.id/index.php/disertasi/article/view/8069.

Kurniawan, H. (2016). Efektifitas Pembelajaran Problem Solving Terhadap Keterampilan Berpikir Kritis. In Seminar Matematika dan Pendidikan Matematika (pp. 47-56). Surakarta: FKIP UNS Surakarta.

Lipman, M. (1987). Critical Thinking: What can it be? Analitic Teaching, 8(1), 5-12.

Lunenburg, F. C. (2011). Critical Thinking and Constructivism Techniques for Improving Student Achievement. National Forum of Teacher Education, 21(3), 1-9. Retrieved from http://www.nationalforum.com/Electronic Journal Volumes/Lunenburg, Fred C. Critical Thinking \& Constructivism V21 N3 2011 NFTJ.pdf.

Miles, M. B., Huberman, A. M., \& Huberman, M. A., Huberman, M. (1994). Qualitative data analysis: An expanded sourcebook. sage.

Moleong, L. J. (2017). Metodologi Penelitian Kualitatif. Bandung: PT Rosda Karya.

Mullis, I. V. S., Martin, M. O., Foy, P., \& Hooper, M. (2015). TIMSS 2015 International Results in Mathematics. Boston: Boston College.

National Council of Teachers of Mathematics. (2000). Principles and standards for school mathematics. Reston VA.

Nurbayani, E. (2012). Penilaian Acuan Patokan (PAP) di Perguruan Tinggi: Prinsip dan 
Operasionalnya. Dinamika Ilmu, 12(1), 1-9

Nuryanti, L., Zubaidah, S., \& Diantoro, M. (2018). Analisis kemampuan berpikir kritis siswa SMP. Jurnal Pendidikan: Teori, Penelitian, dan Pengembangan, 3(2), 155-158.

Riley, M. S. (1984). Development of Children's Problem Solving Ability in Arithmatic. Pittsburgh University.

Rittle-johnson, B., Siegler, R. S., \& Alibali, M. W. (2001). Developing Conceptual Understanding and Procedural Skill in Mathematics : An Iterative Process. Journal of Educational Psychology, 93(2), 346-362. https://doi.org/10.1037//00220663.93.2.346.

Rohaeti, E. E. (2010). Critical and Creative Mathematical Thinking of Junior High School Students. Educationist, IV(2), 99-106.

Sari, Y. I., \& Putra, D. F. (2015). Pengaruh Model Pembelajaran Treffinger Terhadap Kemampuan Berpikir Kritis dan Kreatif Mahasiswa Universitas Kanjuruhan Malang. Jurnal Pendidikan Geografi, 20(2), 30-38.

Scott, L. A. (2017). 21 st Century Skills Early Learning. US: Battelleforkidd.

Widodo, S. A., \& Sujadi, A. A. (2015). Analisis Kesalahan Mahasiswa dalam Memecahkan Masalah Trigonometri. Jurnal Sosiohumaniora, 1(1), 51-63.

Widiantari, N. K. M. P., Suarjana, I. M., \& Kusmariyatni, N. (2016). Analisis Kemampuan Berpikir Kritis Siswa Kelas IV dalam Pembelajaran Matematika. MIMBAR PGSD Undiksha, 4(1), 1-11.

Zetriuslita, Z., Ariawan, R., \& Nufus, H. (2016). Analisis Kemampuan Berpikir Kritis Matematis Mahasiswa dalam Menyelesaikan Soal Uraian Kalkulus Integral Berdasarkan Level Kemampuan Mahasiswa. Infinity Journal, 5(1), 56-65. https://doi.org/10.22460/infinity.v5i1.193. 